\title{
Factors controlling testis descent
}

\author{
Ieuan A Hughes and Carlo L Acerini \\ Department of Paediatrics, Addenbrooke's Hospital, University of Cambridge, Box 116, Hills Road, Cambridge CB2 OQQ, UK \\ (Correspondence should be addressed to I A Hughes; Email: iah1000@cam.ac.uk)
}

\begin{abstract}
Descent of the testis from an intra-abdominal site in foetal life to an extracorporeal location after birth is a mandatory developmental process to ensure that the mature testis promotes normal spermatogenesis. The two phases of transabdominal and inguinoscrotal descent occur approximately during the first and last thirds of gestation respectively. Key anatomical events to release the testis from its urogenital ridge location and to guide the free gonad into the scrotum are the degeneration of the cranio-suspensory ligament and a thickening of the gubernaculum. Androgens play a role in both these processes, particularly with respect to enabling the testis to traverse the inguinal canal in the final phase of descent. Experiments in animals suggest that androgens mediate this effect via the release of calcitonin gene-related peptide by the genitofemoral nerve, but direct evidence for such a mechanism is lacking in humans. The transabdominal phase of descent is under the control of insulinlike 3 (INSL3), a product of the Leydig cells. Definitive evidence of its role in rodent testis descent is illustrated by the phenotype of bilateral cryptorchidism in Insl3 $-/-$ null mice. Circulating levels of INSL3 are higher in boys at puberty, are undetectable in girls and are lower in boys with undescended testes. A minority also have a mutation either in the INSL3 gene or affecting its receptor gene, relaxin/insulin-like family peptide receptor 2 (LGRF8). Other factors that may play a role in testis descent include the anti-Mullerian hormone and members of the HOX gene family. Evidence that the prevalence of undescended testis may be increasing provides a phenotypic readout for the effects of postulated chemicals in the environment interfering in some way with the action of factors that control testis descent. Epidemiological studies point to profound geographical variations in prevalence in countries such as Denmark and Finland. Associations have been found with levels of chemicals labelled as endocrine disruptors being higher in breast milk samples from mothers with cryptorchid boys when compared with controls. The adverse effects of these compounds (e.g. bisphenol A) can be replicated in the offspring of dams exposed during pregnancy. A sensitive marker of an anti-androgen effect of a compound is a reduction in the anogenital distance, an anthropometric measurement that is significantly greater in males compared with females. The observation of an association between the anogenital distance in infant boys and the level of pesticides in the urine of their mothers in late gestation indicates that this has the potential to be a useful surrogate marker of the effects of environmental chemicals on testis descent in human population studies. The rightful place for the testis at birth is in the scrotum in order to provide the temperature differential essential for normal spermatogenesis. Appropriate screening programmes and early surgical intervention are the prerequisites to ensure optimal fertility in adulthood and a considerably lessened risk of testis cancer.
\end{abstract}

European Journal of Endocrinology 159 S75-S82

\section{Introduction}

In most mammals, the testis must descend from the abdomen to an extracorporeal position to provide a lower ambient temperature for normal spermatogenesis. The decrement in intratesticular temperature compared with body temperature in adult males is in the order of $2-4{ }^{\circ} \mathrm{C}(1)$. It is hypothesised that this is the result of evolutionary adaptation to the need for a regulated hyperthermic metabolic milieu in ancestral

This paper was presented at the 5th Ferring International Paediatric Endocrinology Symposium, Baveno, Italy (2008). Ferring Pharmaceuticals has supported the publication of these proceedings. mammals for the function of abdominal organs such as the liver and kidneys (2). Nevertheless, some mammals have continued reproducing despite having testes permanently sited in the abdomen. Thus, the whale manages by virtue of a specialised blood supply that promotes heat exchange.

There is abundant clinical evidence in humans for adverse effects of increased ambient temperature on spermatogenesis (3-7). Varicocele and undescended testis are well-recognised causes of male infertility associated with abnormal spermatogenesis, but lifestyle factors such as the taking of hot baths, sauna use, wearing tight fitting underpants and prolonged sedentary occupations all conspire to raise scrotal skin 
temperature. Modern man is now at risk from the effects of the use of laptop computers actually positioned on laps when in use (8). Scrotal skin temperatures are significantly increased after 15 min of laptop usage and within $1 \mathrm{~h}$ of usage the external undersurface of the laptop can reach $40{ }^{\circ} \mathrm{C}$. Is a current generation of young, high-flying financial city gents at risk of infertility? There has even been concern that the use of plastic lined nappies in infant males may be detrimental to later reproductive function (9). The difference in temperature measured rectally and from the overlying scrotal skin was significantly greater with the use of cotton lined versus plastic lined nappies. A lowering of the rectoscrotal temperature gradient by just $1-2{ }^{\circ} \mathrm{C}$ is sufficient to experimentally suppress spermatogenesis (10). Clearly, it is not possible to extrapolate the findings from the scrotal temperature study in male infants to a risk of infertility, but the infancy period is a time when Sertoli cell mass is established as the supporting cells for germ cell function in adulthood (11).

The time of gestation when the testis has completed its descent into the scrotum varies considerably amongst different mammals (Fig. 1) (12). The human testis is descended generally at birth, in common with the rabbit, pig and horse. By contrast, cattle and deer have testes fully descended early in gestation whereas this is considerably delayed after birth in the dog. Irrespective of the timing, all models share in common a two-phase process of transabdominal and inguinoscrotal descent, which is controlled by different mechanisms.

\section{Embryology of testis descent}

The commitment of the bipotential gonad to testis determination in the urogenital ridge is a prelude to the male gonad starting its long migration to the scrotum. The multiple factors that control testis development in the foetus are reviewed elsewhere (13-16). Figure 2 depicts the formed foetal testis that is destined to differentiate into three functioning cellular components, of which two are already active in foetal life and essential for normal male development. Sertoli cells produce anti-Mullerian hormone $(\mathrm{AMH})$ during a critical short window in early development to cause regression of Mullerian structures. Contemporaneously, Leydig cells produce testosterone in large concentrations to act in a paracrine manner to stabilise the Wolffian ducts and systemically to masculinise the external genitalia. Later, high intratesticular concentrations are required for spermatogenesis. All these androgen effects are mediated by the ligand binding to the intracellular nuclear androgen receptor (AR) and activating androgen-responsive genes (17). The Leydig cell also produces insulin-like 3 (INSL3) that is at least part controlled by human chorionic gonadotrophin (hCG) and luteinising hormone (LH) (18). This peptide, by binding to its receptor leucine-rich repeat-containing G proteincoupled receptor 8 (LGR8), is also a factor in the control of testis descent. An alternative name for this protein reflecting its role in testis descent is G-protein-coupled receptor affecting testis descent, GREAT.

A diagrammatic representation of the anatomy of testis descent is illustrated in Fig. 3. The testis is attached to the diaphragm by the cranio-suspensory ligament that degenerates in the male to allow the release of the testis to migrate across the abdomen. The cranio-suspensory ligament is maintained in the female thus allowing the ovary to retain its pelvic location. There is simultaneous thickening of the gubernaculum in the male, which helps to anchor and retain the testis to the inguinal region while the abdominal cavity is enlarging. The gubernaculum does not enlarge in the female and is retained as the ovarian round ligament. The duration of these two phases of testis descent is depicted in the figure. An interval of around 10 weeks of inactivity between the phases is not readily explained. The gubernaculum reaches out from the abdominal wall of the inguinal region to traverse the pubic region into the scrotum. The processus vaginalis becomes an extension of the abdominal cavity within the

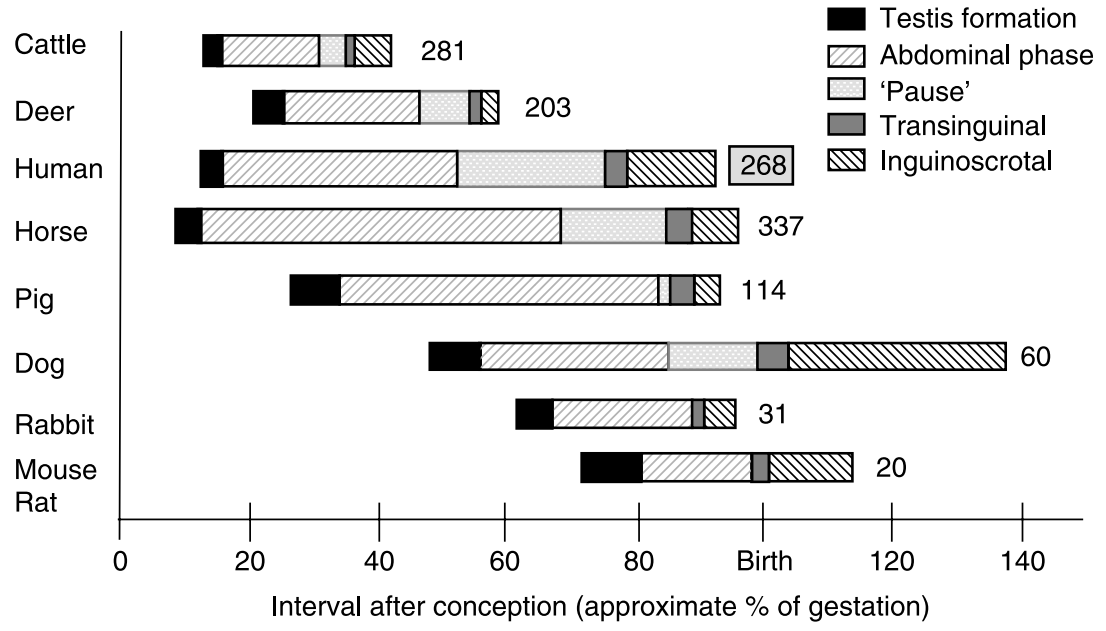

Figure 1 Timing of testis descent in mammals in relation to prenatal and early postnatal chronological age. The length of human gestation is denoted as 268 days (Adapted from ref 12 of with permission of Reproduction). 


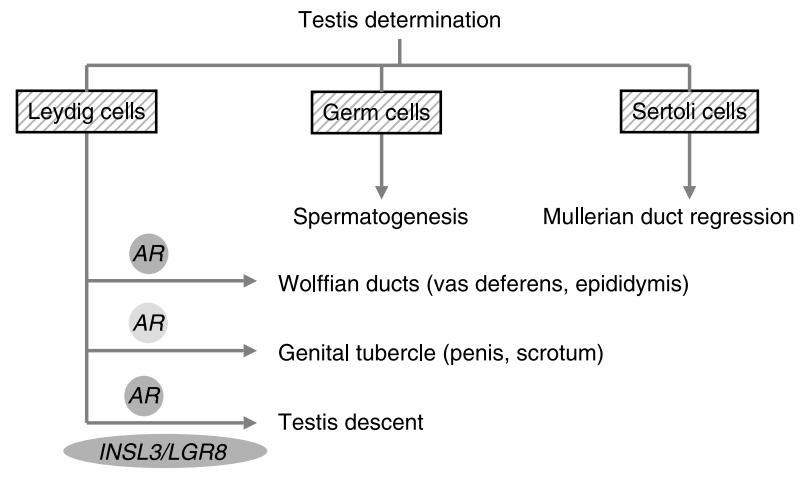

Figure 2 Component cells of the foetal testis and their respective function. AR, androgen receptor; INSL3, insulin-like 3; LGR8, relaxin/insulin-like family peptide receptor 2 .

gubernaculum linking the scrotal and peritoneal cavities. The gubernaculum appears to act as a guide wire for the scrotal descent of the testis. This structure has been likened to a limb bud in forging a bulge in the anterior abdominal wall in the site destined to become the external inguinal ring (19). The simile is supported by evidence of expression in the gubernaculum of HOXA1O and FGF10, growth regulatory genes characteristically found in developing limb buds (20).

The inguinal canal is widened by the effect of the thickening gubernaculum and increased abdominal pressure promotes passage of the testis and epididymis through the canal engulfed by the processus vaginalis. It is estimated that the distance covered in relative terms during this period of testicular migration is around 5-10 $\mathrm{cm}$ to enable the inferior pole of the testis to settle at the bottom of the scrotum. For normal descent to occur, the processus vaginalis closes and thereafter involutes. It is likely that incomplete involution may be an underlying cause of the ascending testis by impeding elongation of the spermatic cord during testis descent (see later).
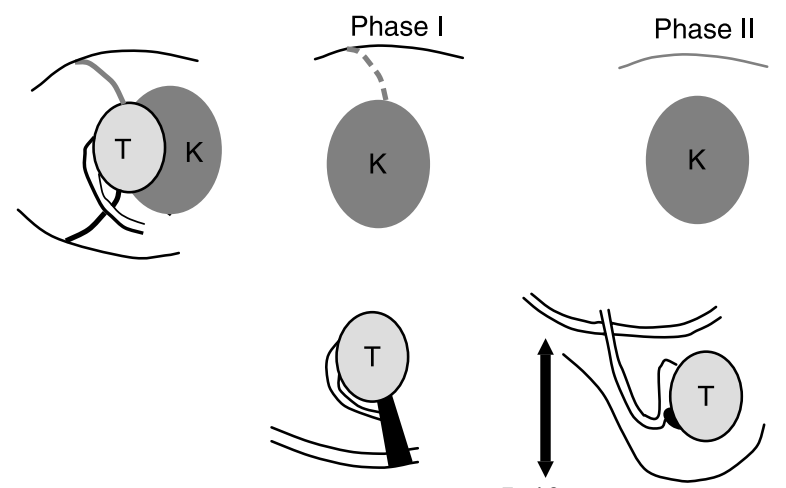

8-15weeks

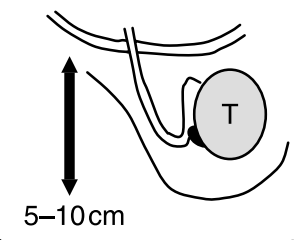

25-35weeks

Figure 3 Descent of the testis represented by two phases, transabdominal (phase I) and inguinoscrotal (phase II). The duration of each phase is indicated in weeks; $5-10 \mathrm{~cm}$ represents the distance traversed by the testis from the inguinal canal to the base of the scrotum. T, testis; K, kidney.

\section{Genetic and hormonal control of testis descent}

\section{Transabdominal phase}

Distinctly separate mechanisms are involved in controlling the two phases of testis descent. Androgen induces regression of the cranio-suspensory ligament to release the testis to descend. Otherwise, androgens are not required for the first phase of testis descent. Studies in disorders associated with defects in androgen biosynthesis show that the testes are invariably descended as far as the inguinal region. In gonadotrophin deficiency such as that occuring in Kallmann and Prader-Willi syndromes, the testes have generally traversed the abdomen. Figure 4 illustrates the location of the testes in a series of cases of androgen biosynthetic disorders and androgen insensitivity syndrome recorded on the Cambridge Disorders of Sex Development database. Even in the complete form of androgen insensitivity syndrome with no scrotal development, a significant number of gonads descend as far as the labia. The pattern of location site was similar in the partial form (partial androgen insensitivity syndrome) whether an AR mutation was identified or not.

The thickening of the gubernaculum, a process crucial for anchoring the testis to the inguinal region, appears to be controlled by INSL3 and its receptor as evidenced by studies in mice. Disruption of the Insl3 or Lgr8 genes results in bilateral intra-abdominal testes and maldeveloped gubernacular $(21,22)$. Furthermore, over-expression of Insl3 in female mice results in descent of the ovaries to the inguinal region and development of a processus vaginalis (23). The role of this peptide in the control of testis descent in humans is less clear cut. Mutational analysis of the INSL3 and LGR8/GREAT genes in boys with either unilateral or bilateral cryptorchidism has revealed only a small minority of cases that harbour sequence changes of functional significance (24). A number of substitutions are reported such as Ala60Thr in INSL3 and Ile160Val in LGR8, but functional studies in vitro show no ligand or receptor dysfunction. However, a Thr222Pro substitution located in the extracellular domain of the LGR 8 receptor resulted in the loss of cAMP generation with increasing concentrations of INSL3 using mutant constructs transiently expressed in 293T cells (25).

INSL3 is a circulating peptide that can be measured by standard immunoassay (26). Levels are increased at puberty and adulthood while they are undetectable in females. The dependency on gonadotrophic control is illustrated by higher levels in cord blood and in serum from 3-month male infants compared with prepubertal boys (27). This study also reported a significant reduction in cord blood INSL3 levels of persistently cryptorchid boys and a significant increase in the serum LH:INSL3 ratio in 3-month-old persistently cryptorchid boys. It is clear that INSL3 binding to its seven transmembrane G-protein-coupled receptor 


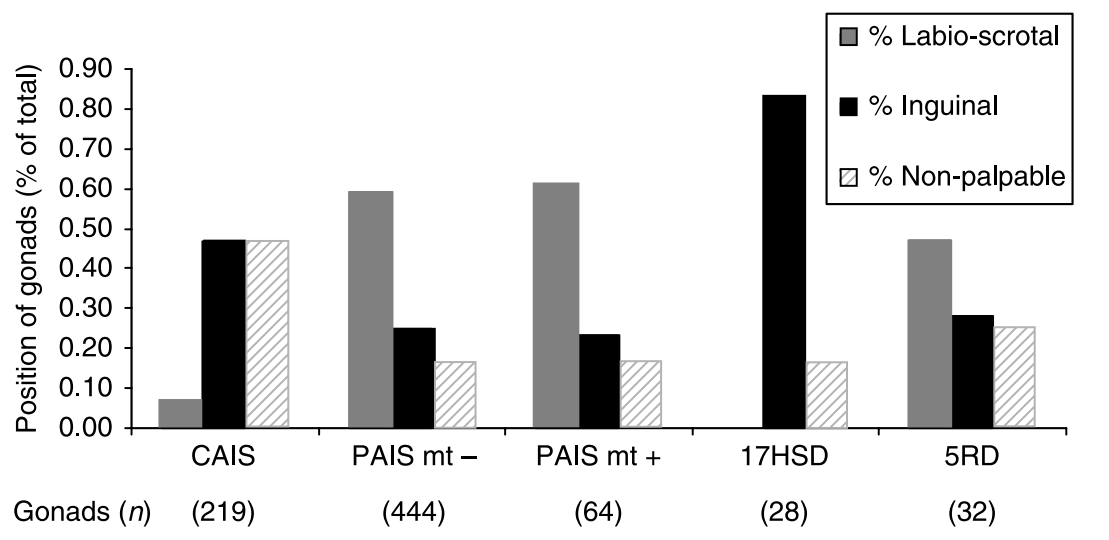

Figure 4 Location of testes in disorders of sex development (DSD) recorded on the Cambridge DSD Database. CAIS, complete androgen insensitivity syndrome; PAIS, partial androgen insensitivity syndrome $(\mathrm{mt}-$, AR mutation not identified; $\mathrm{mt}+, \mathrm{AR}$ mutation identified); 17HSD, 17 $\beta$-hydroxysteroid dehydrogenase deficiency; 5RD, $5 \alpha$-reductase deficiency.

does play some role in transabdominal descent of the testis in humans.

Another factor implicated as having some role in the first phase of testis descent is the Sertoli cell product, AMH (28). Mutations in the gene for the ligand or the AMH receptor cause the persistent Mullerian duct syndrome in males, which not only leads to retention of a uterus and Fallopian tubes, but also maldescent of the testis (29). However, it is likely that the cause is mechanical in nature because of the testis being attached to a Fallopian tube, rather than the syndrome indicating direct evidence for a role of $\mathrm{AMH}$ in testis descent in the human. Also, AMH receptor-deficient mice have normal testis descent (30). Disruption of some Hox genes in the mouse lead to cryptorchidism but this is probably not relevant to human studies of cryptorchidism (18).

\section{Inguinoscrotal phase}

Androgens predominantly control the second phase of testis descent into the scrotum. The steroid functions by activating the nuclear AR to induce transcription of androgen-responsive genes. It is axiomatic that any one of the numerous causes leading to a defect in androgen production or action can manifest with failure of testis descent. Rarely is this an isolated finding, the phenotype usually comprising an associated hypospadias, bifid scrotum and micropenis (31). However, in a large study of males with infertility, $1.7 \%$ had a mutation in the $A R$ gene with some displaying a history of cryptorchidism (32). Isolated cryptorchidism is an unlikely consequence of an AR mutation but may be associated with a mild phenotype such as a history of gynaecomastia and impaired sperm production.

The AR gene is characterised by two polymorphic regions in exon 1 comprising CAG and GGC repeats that encode for variable stretches of glutamine and glycine respectively. There is an inverse relationship between the number of CAG repeats and the transcriptional activity of the AR when studied in vitro (33). There is also some biological plausibility to experimental observation as there are clear associations with shorter CAG

repeats and disorders linked to enhanced androgen action. These include premature adrenarche and acne in females, and an increased risk of metastatic disease in prostate cancer $(34,35)$. Conversely, longer CAG repeats have been associated with idiopathic hypospadias, undescended testes and decreased sperm counts (36-38). The association with cryptorchidism is stronger when combined analysis of CAG and GGC repeat lengths is performed (39).

There is abundant circumstantial evidence for the effect of androgens promoting descent of the testis into the scrotum. This includes the completion of testis descent, which often occurs after birth commensurate with the neonatal surge in testosterone levels (40). Furthermore, hCG injections that produce a significant rise in testosterone levels have been a time-honoured method for medical management of undescended testis (41). It seems that a high local concentration of testosterone is required to mediate these effects, but what is the mechanism? Experiments in rodents point to the role of the genitofemoral nerve and its neurotransmitter, calcitonin gene-related peptide (CGRP). Androgens mediate a sex-dimorphic differentiation of the genitofemoral nerve with release of CGRP that causes a rhythmic contraction of the gubernaculums (42). Prenatal administration of an anti-androgen inhibits development of the genitofemoral nerve nucleus in the rat and testis maldescent (43). If the genitofemoral nerve is transected, this leads to a failure of gubernacular migration and normal testis descent (44). Evidence for the role of this nerve and its CGRP transmitter in testis descent in humans is less persuasive than in rodents. Children with neural tube defects such as spina bifida have undescended testes, but such a major congenital malformation is too non-specific an example to invoke a similar mechanism for inguinoscrotal descent operating in humans (Fig. 5).

\section{Environmental factors}

Epidemiological studies suggest that an increase in prevalence of cryptorchidism has occurred in recent 


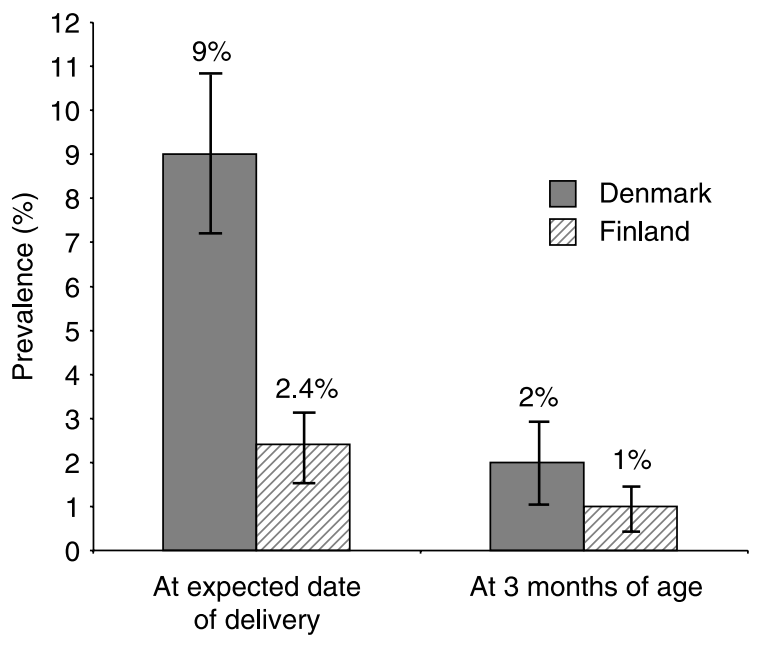

Figure 5 Comparison of prevalence of cryptorchidism in Denmark and Finland (reproduced from ref (46) with permission of the Lancet).

years (45). Prevalence figures vary by geographical region but a figure of $2-4 \%$ is generally considered to be the range for full-term male infants. Cryptorchidism is certainly the commonest birth defect in males. There is a remarkably higher prevalence of cryptorchidism in Denmark compared with, for example, Finland (Fig. 6) (46). The prevalence in both populations falls by 3 months of age reflecting the effect of increased ambient testosterone levels at this time, but the prevalence of testis maldescent is still twofold greater in the Danish population. These observations of changing temporal trends and geographical variability in prevalence suggest a role for environmental factors in the aetiology of cryptorchidism. Humans are exposed to more than 80000 chemicals some of which have properties that have estrogenic effects or can interfere with androgen synthesis and action. These include pesticides, phthalates and bisphenol A (47). Studies in rodents can replicate the effects of androgen insufficiency by administering such compounds to pregnant dams and demonstrating undescended testes, hypospadias and reduced anogenital distance in male offspring (48). The latter morphological marker is a sensitive bioassay of androgen action in animal reproductive toxicology studies (49). Data are available on anogenital distance in newborns measured according to the anatomical landmarks illustrated in Fig. 6 (50). The distance is generally twofold greater in males than females. The technique was applied to a study of prenatal exposure to phthalates as determined by measurement of four phthalate metabolites in prenatal maternal urine samples (51). The anogenital distance in boys was calculated at a mean age of 16 months and was significantly decreased with increasing phthalate levels. There was also a trend for a shorter anogenital distance in boys with incomplete testis descent. In a cohort of boys with hypospadias or cryptorchidism, the anogenital distance quantified as anterior and posterior anoscrotal distance and measured at the time of surgery was significantly shorter in hypospadias but not in cryptorchid boys compared with normal boys (52).

Population studies are required to determine whether trends in the prevalence of relatively common male reproductive tract disorders such as hypospadias and cryptorchidism are related to environmental factors. To that end, a Cambridge Baby Growth Study is ongoing which comprises the recruitment of pregnant women at antenatal booking to follow their progress through gestation (see http://www.medschl.cam.ac.uk/paediatrics). A range of biological samples for analysis of relevant hormones and chemical endocrine disrupters are being collected from the mother and thereafter, from her offspring until 2 years of age. Detailed anthropometric measurements of the infant include birth weight and length, precise location of the testes, anogenital distance and repeated at intervals thereafter. A case
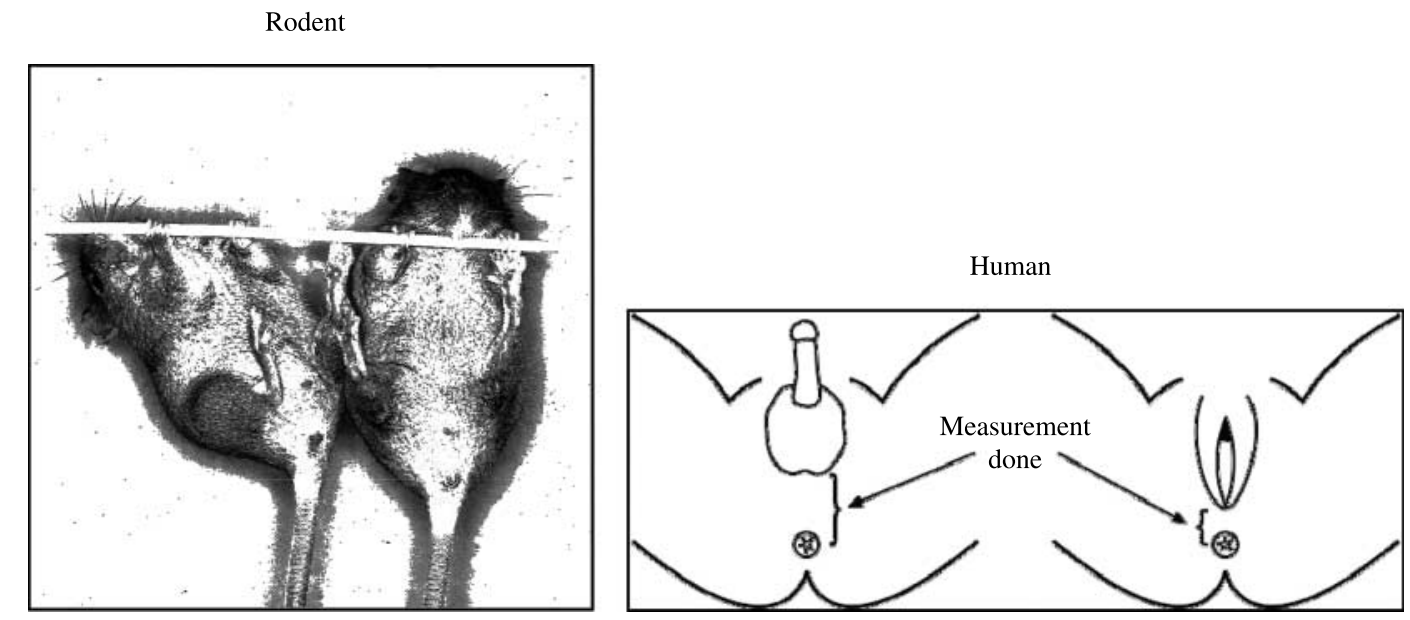

Figure 6 Landmarks for measurement of anogenital distance (AGD) in male and female infants. Also shown is the AGD in an XY mouse compared with an XX male mouse transgenic for the Sry gene. The AGD is indistinguishable. 
control study will evaluate any differences found between normal boys and boys with genital anomalies. It is important to recognise that any cause of testis maldescent postulated to be attributed to environmental factors must be evaluated in relation to a number of known associations with undescended testis (Table 1).

A common denominator for many of the associations with undescended testis is some interference with the production or action of testosterone, which is clearly required to enable the testis to assume its low scrotal position by birth or soon thereafter. Reliable newborn examination is the bedrock for detecting undescended testis early, together with a suitable screening programme that will ensure the ascending testis is also not missed $(53,54)$. The ascending testis or acquired (as opposed to congenital) undescended testis presents between 5 and 10 years of age and provides a significant amount of the orchidopexy load $(55,56)$. It has been debated whether the preferred management should be an expectant policy in these cases of waiting for spontaneous descent at puberty rather than routinely performing orchidopexy (57). It is not clear whether the ascending testis is merely the result of a mechanical impediment to elongation of the spermatic cord from incomplete involution of the processus vaginalis (as previously mentioned), or is also linked to some cause of androgen dysfunction. The Cambridge epidemiological study may provide some insights if sufficient numbers of cases of congenital and acquired undescended testis are recruited in due course.

The correct place for the testis by birth or soon afterwards in the human is to be firmly anchored to the base of the scrotum. There is abundant evidence for a strong association between testis maldescent and later risk of infertility and testis cancer $(58,59)$. Consequently, it is important that appropriate screening programmes and early surgery are implemented as preventative measures. The risk of testis cancer is significantly decreased if orchidopexy for undescended testis is performed before puberty (60). In reality, it is recommended that orchidopexy is undertaken as early as $6-12$ months of age to ensure the optimal germ cell development that occurs during the first year of life $(61,62)$.

In conclusion, the descent of the testis in humans is controlled predominantly by androgens coordinating a combined degeneration and thickening of two ligaments respectively, which anchor the foetal male gonad. The

Table 1 Some factors associated with undescended testis.

\begin{tabular}{ll}
\hline Low birth weight & \\
Prematurity & \\
Low parity & Hypospadias \\
Twinning & Male infertility \\
Maternal alcohol & Testis cancer \\
Maternal caffeine & \\
Maternal smoking & \\
Gestational diabetes & \\
\hline
\end{tabular}

release and transfer of the testis to the scrotum occur in two phases. The transabdominal phase is controlled in the rodent by INSL3, whereas the role of this Leydig cell protein product is less clear in the human. Equally, evidence for the release of CGRP by the sexually dimorphic genitofemoral nerve to stimulate gubernaculum rhythmicity is less persuasive in the human than it is in the rodent model. There is strong clinical evidence for the role of androgens completing testis descent at or shortly after birth.

\section{Acknowledgements}

We thank the research nurses for there work on behalf of the Cambridge Birth Growth Study. This project is supported by the European Union, the Medical Research Council, the Birth Defects Foundation and the Cambridge NIHR Biomedical Research Centre.

\section{Disclosure}

This paper forms part of a European Journal of Endocrinology supplement, supported by Ferring Pharmaceuticals. The authors disclose no potential conflicting relationship with Ferring. This article was subject to rigorous peer review before acceptance and publication.

\section{References}

1 Thonneau P, Bujan L, Multigner L \& Mieusset R. Occupational heat exposure and male fertility: a review. Human Reproduction 199813 2122-2125.

2 Werdelin L \& Nilsonne A. The evolution of the scrotum and testicular descent in mammals: a phylogenetic view. Journal of Theoretical Biology 1999196 61-72.

3 Thonneau P, Ducot B, Bujan L, Mieusset R \& Spira A. Heat exposure as a hazard to male fertility. Lancet $1996347204-205$.

4 Bujan L, Daudin M, Charlet JP, Thonneau P \& Mieusset R. Increase in scrotal temperature in car drivers. Human Reproduction 200015 $1355-1357$.

5 Jung A, Leonhardt F, Schill WB \& Schuppe HC. Influence of the type of undertrousers and physical activity on scrotal temperature. Human Reproduction 200520 1022-1027.

6 Schoor RA, Elhanbly SM \& Niederberger C. The pathophysiology of varicocele-associated male infertility. Current Urology Reports 2001 2 432-436.

7 Ivell R. Lifestyle impact and the biology of the human scrotum. Reproductive Biology and Endocrinology 20075 15-22.

8 Sheynkin Y, Jung M, Yoo P, Schulsinger D \& Komaroff E. Increase in scrotal temperature in laptop computer users. Human Reproduction 200420 452-455.

9 Partsch C-J, Aukamp M \& Sippell WG. Scrotal temperature is increased on disposable plastic lined nappies. Archives of Disease in Childhood 200083 364-368.

10 Mieusset R \& Bujan L. The potential of mild testicular heating as a safe, effective and reversible contraceptive method for men. International Journal of Andrology 199417 186-191.

11 Jorgensen N, Carlsen E, Nermoen I, Punab M, Suominen J, Andersen A-G, Andersson AM, Haugen TB, Horte A, Jensen TK, Magnus O, Petersen JH, Vierula M, Toppari J \& Skakkebaek NE. East-West gradient in semen quality in the Nordic-Baltic area: a study of men from the general population in Denmark, Norway, Estonia and Finland. Human Reproduction 200217 2199-2208.

12 Amann RP \& Veeramachaneni DNR. Cryptorchidism in common eutherian mammals. Reproduction 2007133 541-561. 
13 Ross AJ \& Capel B. Signaling at the crossroads of gonad development. Trends in Endocrinology and Metabolism 200516 19-25.

14 Wilhelm D \& Koopman P. The makings of maleness: towards an integrated view of male sexual development. Nature Reviews. Genetics 20067 620-631.

15 Achermann JC \& Hughes IA. Disorders of sex development. In William's Textbook of Endocrinology, edn 11, pp 783-848. Eds H Kronenberg, S Melmed, K Polonsky \& PR Larsen, Philadelphia: Saunders Elsevier, 2007.

16 Sekido R \& Lovell-Badge R. Sex determination involves synergistic action of SRY and SF1 on a specific Sox9 enhancer. Nature 2008 453 930-934.

17 Gobinet J, Poujol N \& Sultan C. Molecular action of androgens. Molecular and Cellular Endocrinology 2002198 15-24.

18 Foresta C, Zuccarello D, Garolla A \& Ferlin A. Role of hormones, genes and environment in human cryptorchidism. (Eprint April 24) Endocrine Reviews 200829 560-580.

19 Nightingale SS, Western P \& Hutson JM. The migrating gubernaculum grows like a limb bud. Journal of Pediatric Surgery 200843 387-390.

20 Ohuchi H, Nakagawa T, Yamamoto A, Araga A, Ohata T, Ishimaru Y, Yoshioka H, Kuwana T, Nohno T, Yamasaki M, Itoh N \& Noji S. The mesenchymal factor, FGF10, initiates and maintains the outgrowth of the chick limb bud through interaction with FGF8, an apical ectodermal factor. Development $19971242235-2244$.

21 Zimmermann S, Steding G, Emmen JM, Brinkmann AO, Nayernia K, Holstein AF, Engel W \& Adham IM. Targeted disruption of the Insl3 gene causes bilateral cryptorchidism. Molecular Endocrinology 199913 681-691.

22 Overbeek PA, Gorlov IP, Sutherland RW, Houston JB, Harrison WR, Boettger-Tong HL, Bishop CE \& Agoulnik AI. A transgenic insertion causing cryptorchidism in mice. Genesis 200130 26-35.

23 Adham IM, Steding G, Thamm T, Büllesbach EE, Schwabe C, Paprotta I \& Engel W. The overexpression of the Ins13 in female mice causes descent of the ovaries. Molecular Endocrinology 2002 16 244-252.

24 Yamazawa K, Wada U, Sasagawa I, Aoki K, Katsuhiko U \& Ogata T. Mutation and polymorphism analyses of INSL3 and LGR 8/GREAT in 62 Japanese patients with cryptorchidism. Hormone Research $20076773-76$.

25 Bogatcheva NV, Ferlin A, Feng S, Truong A, Gianesello L, Foresta C \& Agoulnik AI. T222P mutation of the insulin-like 3 hormone receptor LGR 8 is associated with testicular maldescent and hinders receptor expression on the cell surface membrane. American Journal of Physiology. Endocrinology and Metabolism 2006292 E138-E144.

26 Bay K, Hartung S, Ivell R, Schumacher M, Jurgensen D, Jorgensen N, Holm M, Skakkebaek NE \& Andersson A-M. Insulin-like factor 3 (INSL3) serum levels in 135 normal men and 85 men with testicular disorders: relationship to the LH-testosterone axis. Journal of Clinical Endocrinology and Metabolism 200590 3410-3418.

27 Bay K, Virtanen HE, Hartung S, Ivell R, Main KM, Skakkebaek NE, Andersson A-M, The Nordic Cryptorchidism Study Group \& Toppari J. Insulin-like factor 3 levels in cord blood and serum from children: effects of age, postnatal hypothalamic-pituitary-gonadal axis activation and cryptorchidism. Journal of Clinical Endocrinology and Metabolism 200792 4020-4027.

28 Josso N, di Clemente N \& Gouedard L. Anti-Mullerian hormone and its receptors. Molecular and Cellular Endocrinology 2001179 25-32.

29 Josso N, Belville C, di Clemente N \& Picard JY. AMH and AMH receptor defects in persistent Müllerian duct syndrome. Human Reproduction Update 200511 351-356.

30 Behringer RR, Finegold MJ \& Cate RL. Müllerian-inhibiting substance function during mammalian sexual development. Cell $199479415-425$.
31 Deeb A, Mason C, Lee YS \& Hughes IA. Correlation between genotype, phenotype and sex of rearing in 111 patients with partial androgen insensitivity syndrome. Clinical Endocrinology $20056356-62$.

32 Ferlin A, Vinanzi C, Garolla A, Selice R, Zuccarello D, Cazzadore C \& Foresta C. Male infertility and androgen receptor gene mutations: clinical features and identification of seven novel mutations. Clinical Endocrinology 200665 606-610.

33 Chamberlain NL, Driver ED \& Miesfield RL. The length and location of CAG trinucleotides repeats in the androgen receptor $\mathrm{N}$-terminal domain affect transactivation function. Nucleic Acids Research 199422 3181-3186.

34 Ibanez L, Ong KK, Mongan N, Jääskeläinen J, Marcos MV, Hughes IA, de Zegher F \& Dunger DB. Androgen receptor gene CAG repeat polymorphism in the development of ovarian hyperandrogenism. Journal of Clinical Endocrinology and Metabolism 200388 3333-3338.

35 Nelson KA \& Witte JS. Androgen receptor CAG repeats and prostate cancer. American Journal of Epidemiology 2002155 883-890.

36 Lim HN, Nixon RM, Chen H, Hughes IA \& Hawkins JR. Evidence that longer androgen receptor polyglutamine repeats are a causal factor for genital abnormalities. Journal of Clinical Endocrinology and Metabolism 200186 3207-3210.

37 Silva-Ramos M, Oliveira JM, Cabeda JM, Reis A, Soares J \& Pimenta A. The CAG repeat within the androgen receptor gene and its relationship to cryptorchidism. International Brazilian Journal of Urology 200632 330-334.

38 Davis-Dao CA, Tuazon ED, Sokol RZ \& Cortessis VK. Male infertility and variation in CAG repeat length in the androgen receptor gene: a meta-analysis. Journal of Clinical Endocrinology and Metabolism 200792 4319-4326.

39 Aschim EL, Nordenskjöld A, Giwercman A, Lundin KB, Ruhayel Y, Haugen TB, Grotmol T \& Giwercman YL. Linkage between cryptorchidism, hypospadias, and GGN repeat lengths in the androgen receptor gene. Journal of Clinical Endocrinology and Metabolism 200489 5105-5109.

40 Pierik FH, Deddens JA, Burdorf A, de Jong FH \& Weber RFA. The hypothalamus-pituitary-testis axis in boys during the first six months of life: a comparison of cryptorchidism and hypospadias cases with controls. Journal of Andrology 200831 1-9.

41 Henna MR, Del Nero RG, Sampaio CZ, Atallah AN, Schettini ST, Castro AA \& Soares BG. Hormonal cryptorchidism therapy: systematic review with metanalysis of randomized clinical trials. Pediatric Surgery International 200420 357-359.

42 Hutson JM, Hasthorpe S \& Heyns CF. Anatomical and functional aspects of testicular descent and cryptorchidism. Endocrine Reviews 199718 259-280.

43 Shono T, Suita S, Kai H \& Yamaguchi Y. Short-time exposure to Vinclozolin in utero induces testicular maldescent associated with a spinal nucleus alteration of the genitofemoral nerve in rats. Journal of Pediatric Surgery 200439 217-219.

44 Shono T, Zakaria O, Imajima T \& Suita S. Does proximal genitofemoral nerve division induce testicular maldescent or ascent in the rat? BJU International 199983 323-326.

45 Virtanen HE \& Toppari J. Epidemiology and pathogenesis of cryptorchidism. Human Reproduction Update 200714 49-58.

46 Boisen KA, Kaleva M, Main KM, Virtanen HE, Haavisto AM, Schmidt IM, Chellakooty M, Damgaard IN, Mau C, Reunanen M, Skakkebaek NE \& Toppari J. Difference in prevalence of congenital cryptorchidism in infants between two Nordic countries. Lancet 2004363 1264-1269.

47 Acerini CL \& Hughes IA. Endocrine disrupting chemicals: a new and emerging public health problem? Archives of Disease in Childhood 200691 633-641.

48 Welsh M, Saunders PT, Fisken M, Scott HM, Hutchison GR, Smith LB \& Sharpe RM. Identification in rats of a programming window for reproductive tract masculinisation, disruption of which leads to hypospadias and cryptorchidism. Journal of Clinical Investigation $2008 \mathbf{1 1 8} 1479-1490$. 
49 Hotchkiss AK, Lambright CS, Ostby JS, Parks-Saldutti L, Vandenbergh JG \& Gray LE Jr. Prenatal testosterone exposure permanently masculinizes anogenital distance, nipple development, and reproductive tract morphology in female SpragueDawley rats. Toxicological Sciences 200796 335-345.

50 Salazar-Martinez E, Romano-Riquer P, Yanaez-Marquez E, Longnecker MP \& Hernandez-Avila M. Anogenital distance in human male and female newborns: a descriptive, cross-sectional study. Environmental Health 20043 8-14.

51 Swan SH, Main KM, Liu F, Stewart SL, Kruse RL, Calafat AM, Mao CS, Redmon JB, Ternand CL, Sullivan S, Teague JL \& Study for Future Families Research Team, . Decrease in anogenital distance among male infants with prenatal phthalate exposure. Environmental Health Perspectives 2005113 1056-1061.

52 Hsieh MH, Breyer BN, Eisenberg ML \& Baskin LS. Associations among hypospadias, cryptorchidism, anogenital distance and endocrine disruption. Current Urology Reports 20089 137-142.

53 Redman JF. The ascending (acquired undescended) testis: a phenomenon? BJU International 200595 1165-1167.

54 Agarwal PK, Diaz M \& Elder JS. Retractile testis - is it really a normal variant? Journal of Urology 2006175 1496-1499.

55 Hutson JM. Treatment of undescended testes - time for a change in European traditions. Acta Paediatrica 200796 608-610.

56 Martin JDC. Further evidence for acquired undescended testicle in the UK and its incompatibility with current recommendations in the Hall Report. Journal of Pediatric Urology 20062 392-397.
57 Hack WWM, van der Voort-Doedens LM, Sijstermans K, Meijer RW \& Pierik FH. Reduction in the number of orchidopexies for cryptorchidism after recognition of acquired undescended testis and implementation of expectative policy. Acta Paediatrica $200796915-918$.

58 Richiardi L, Pettersson A \& Akre O. Genetic and environmental risk factors for testicular cancer. International Journal of Andrology $200730230-240$.

59 Olesen IA, Sonne SB, Hoei-Hansen CE, Rajpert-DeMeyts E \& Skakkebaek NE. Environment, testicular dysgenesis and carcinoma in situ testis. Best Practice and Research. Clinical Endocrinology and Metabolism 200721 462-478.

60 Pettersson A, Richiardi L, Nordenskjold A, Kaijser M \& Akre O. Age at surgery for undescended testis and risk of testicular cancer. New England Journal of Medicine 2007356 1835-1841.

61 Hadziselimovic F, Hocht B, Herzog B \& Buser MW. Infertility in cryptorchidism is linked to the stage of germ cell development at orchidopexy. Hormone Research 200768 46-52.

62 Ritzen EM, Bergh A, Bjerknes R, Christiansen P, Cortes D, Haugen SE, Jorgensen N, Kollin C, Lindahl S, Läckgren G, Main KM, Nordenskjöld A, Rajpert-De Meyts E, Söder O, Taskinen S, Thorsson A, Thorup J \& Virtanen H. Nordic consensus on treatment of undescended testes. Acta Paediatrica 200796 638-643.

Received 13 June 2008

Accepted 2 July 2008 